\title{
The Role of Female Labour in Industrial Restructuring: New production processes and labour market relations in the Istanbul clothing industry
}

\section{AYDA ERAYDIN \& ASUMAN ERENDIL}

To cite this article: AYDA ERAYDIN \& ASUMAN ERENDIL (1999) The Role of Female Labour in Industrial Restructuring: New production processes and labour market relations in the Istanbul clothing industry, Gender, Place and Culture: A Journal of Feminist Geography, 6:3, 259-272, DOI: 10.1080/09663699925024

To link to this article: https://doi.org/10.1080/09663699925024

里 Published online: 14 Jul 2010.

Submit your article to this journal $₫$

Џ Article views: 218

Citing articles: 17 View citing articles 
Gender, Place and Culture, Vol. 6, No. 3, pp. 259-272, 1999

\title{
The Role of Female Labour in Industrial Restructuring: new production processes and labour market relations in the Istanbul clothing industry
}

\author{
AYDA ERAYDIN, Middle East Technical University, Turkey \\ ASUMAN ERENDIL, Bilkent University, Turkey
}

\begin{abstract}
For many industries, a new production system characterised principally by flexibility has become one of the key means of achieving competitive advantage in world markets. In traditional industrial sectors flexibility in the organisation of production is based upon subcontracting, within which female labour is of undisputed importance. In this article, research on female labour in the Istanbul clothing industry is used to investigate these processes of industrial restructuring. Particular attention is drawn to changes in women's attitude to work and in their responses to working conditions, which have important consequences for the industry itself.
\end{abstract}

\section{Introduction}

Since the economic crisis of the 1970s, structures of production have changed considerably throughout the world. New ways of organising production have become necessary in order to compete effectively, with the capacity to utilise global interrelationships and networks acquiring particular importance (Lipietz, 1986; Storper \& Scott, 1986; Storper \& Walker, 1989; Tickell \& Peck, 1992). In almost all discussions of industrial restructuring the importance of female labour is emphasised. Alongside early studies that stressed the significance of female labour supply in the restructuring process (Massey, 1984), special attention has been paid to homeworking (Allen \& Wolkowitz, 1987; Beneria \& Roldan, 1987; Benton, 1989; Peck, 1992; Phizacklea \& Wolkowitz, 1995) and to the increasing involvement of women in the informal economy (Castells \& Portes, 1989; Benton, 1990; Lawson, 1992; Cheng \& Gereffi, 1994).

Various statistics support this focus on female labour. In industrialised countries rates of female employment continue to rise, while in developing countries women are taking an increasing share of employment in the manufacturing sector, especially where it is oriented principally to the export of goods (Horton, 1996). In Turkey, as elsewhere, the number of female employees and employers in the manufacturing industry has been growing. For example, between 1980 and 1992 the number of women in employment increased by $76 \%$, whereas the rate of increase for men was only $11 \%$. While women still account for only $25 \%$ of the total employment in manufacturing industries, their share has been increasing rapidly in labour-intensive sectors, and especially in clothing production. 
In this article, we use evidence concerning female labour in the Istanbul clothing industry to examine the links between industrial restructuring and changing labour market conditions. We argue that the restructuring of production not only generates new labour processes, but also creates new relations between home and work. We suggest that women's attitudes towards, and responses to, new employment opportunities play a vital role in these processes.

The article is divided into three main sections. First, following a brief discussion of theoretical debates, we summarise the development of the Istanbul clothing industry, setting in context the study discussed here. In the second section we explore the attributes of the workforce employed in the clothing industry, drawing particular attention to changes in the characteristics of female employees. We conclude by discussing the impact of these changing characteristics on competitive advantage in the clothing industry.

\section{Female Labour in Industrial Restructuring: the case of Istanbul's clothing industry}

(a) Theoretical Positions

Theories of economic restructuring and the emergence of new systems of production have focused mainly on forms of flexibility that enable producers to adapt to volatile conditions in globalised markets. The use of subcontracting is one of the principal characteristics of these new systems of production, and this generates changes in requirements for, and the organisation of, labour in production processes (Benton, 1990; Lawson, 1992; Peck, 1992). Several studies have explored the impact of restructuring and flexible work organisation on labour processes and labour markets (Storper \& Walker, 1983, 1989; Massey, 1984; Scott \& Storper, 1986; Peck, 1996). However, while these studies consider gender as a characteristic of labour, they do not view gender divisions of labour as an integral part of restructuring processes (Christopherson, 1989; Jenson, 1994).

The role of gender in industrial restructuring has been theorised in two main ways. One approach emphasises the role of women in the family and domestic divisions of labour, arguing that gender divisions in the home place women in a disadvantageous position in labour markets (Hartmann, 1987; Kessler-Harris \& Sacks, 1987; Walby, 1990). From this perspective, gender inequalities in labour markets arise from cultural factors that discourage women from working outside the home or that accord priority to their domestic roles (Prieto, 1986; Lamphere, 1987; Beneria \& Roldan, 1987; Pessar, 1994; Stratigaki \& Vaiou, 1994). For example, patriarchal relations within families, together with broader sociocultural expectations, may force women to accept temporary jobs when additional income is required without bringing any change to their domestic responsibilities (Mies, 1986; Pessar, 1994; White, 1994). The second approach explains the disadvantaged position of women at work in terms of the structure of the labour market itself. According to this perspective the labour market is divided between a primary sector required to meet the technological needs of producers, and a secondary labour market consisting of other workers whose particular skills are expendable and who must therefore accept lower wages and insecure conditions (Doeringer \& Piore, 1985). Women are generally confined to the latter (Benton, 1990).

These two different approaches intersect around the relationship between gender and the informal sector. According to the latter the informal sector necessarily draws upon the secondary labour market within which women are numerous. The former treats the 
informal sector as an outcome of the deregulation of labour markets, which enables female labour to be drawn upon in different ways, including 'homeworking'. Accordingly, within both perspectives industrial restructuring is understood to have increased women's share of employment because of absolute and relative growth in the number of jobs that are temporary, low paid and without social security; that is, the kind of jobs into which women are propelled whether because of their domestic roles or labour market structures (Beneria \& Roldan, 1987; Pessar, 1994).

While these theoretical perspectives increase our understanding of the ways in which industrial restructuring, gender divisions and labour markets interact (Peck, 1992), they fail to consider workers as 'active agents' in the processes in which they participate. Consequently the individual strategies and aspirations of individual employees responding to changing characteristics of labour markets are not taken into account. While it is undoubtedly true that 'labour processes [such as gender divisions] are also shaped by labour markets' (Peck, 1992; p. 685), women's attitudes towards employment opportunities and their economic strategies require further attention if the role of female labour in industrial restructuring is to be understood.

\section{(b) The Development and Restructuring of the Clothing Industry}

As in many developing countries, the Turkish clothing industry has increasingly led the country's export sector. A commercial textile industry, which is the basis of clothing production, has flourished since the beginning of this century. Significant expansion came in the $1950 \mathrm{~s}$, made possible by increasing cotton production. In the early $1970 \mathrm{~s}$ entrepreneurs, typically with long experience in domestic production, began to address opportunities for export. Consequently this sector experienced an investment boom at the time of the economic crisis of the 1970s (Eraydin, 1993). In the mid-1980s, when crisis conditions were relieved, the existence of substantial production capacity enabled textiles to become Turkey's most important export product (Ansal, 1995). Moreover, increasing government support for export-oriented production combined with the strength of the textile industry itself to support rapid expansion in the manufacture of finished clothing.

The 1980s witnessed a turning point in economic policy in Turkey, from the protectionist attitudes that dominated prior to this period (Kazgan, 1985, Boratav, 1988) to increasing integration into international markets. While this greatly expanded opportunities for foreign trade and exchange, in 1984 major structural changes further liberalised trade by dismantling foreign exchange controls and quotas on imports, and by revising tariffs (Olgun \& Togan, 1984). Export-oriented firms therefore began to work in a more competitive environment [1].

Production for export encouraged by liberalisation has also been supported by direct government support and by the falling costs of labour (Senses, 1989). In the first half of the 1980s direct subsidies to export sectors reached $20 \%$ of the total cost of production. Concurrently, the power of labour unions on the labour market was reduced by new laws ushered in by the coup d'état so that wages have reduced dramatically from an index of 100 in 1979 to 71 in 1982 and 68 in 1985. This trend has made labour-intensive production, such as finished clothing, increasingly competitive internationally.

Several institutions concerned with exportation emerged in the early 1980s, including foreign trade companies, associations of small exporters, sectoral associations and semi-public exporter associations (Eraydin, 1993). These new institutions, together with financial incentives, attracted many firms into export activities and the value of such 
exports rose dramatically, from approximately US\$1400 million in 1980 , to US\$13,000 million in 1990 and US\$21,600 million in 1995 (at current prices) (Kazgan, 1985; Senses, 1989). In the initial stages of export-led growth, the clothing industry had a small share in total exports since clothing firms were generally small production units with less experience in export markets. However, this changed dramatically in the second half of the 1980s: clothing exports amounted to approximately US\$130 million in 1980 (9\% of total exports), US $\$ 1,200$ million in 1985 (9\% of total exports) and US\$6,100 million in 1995 (28\% of total exports).

In the mid-1980s, clothing firms producing for Western Europe concentrated on high quality and high value-added products, while other firms concentrated on highly standardised and low quality production for Eastern Europe and Russia. However, studies of the extensive subcontracting arrangements operating revealed that these two segments were not completely separate (Cinar, et al., 1988; Kayasu, 1995; Eraydin \& Erendil, 1998). The subcontracting of sewing to small firms led to more complex relationships between firms, creating intricate networks through which production is organised. These networks enabled costs to be minimised and facilitated swift responses to changing demand (Pincheson, 1993, 1994). This system has continued into the 1990s, with labour-intensive stages of production subcontracted to small firms (Eraydin, 1994; Kaytaz, 1994) that mainly employ women, including homeworkers (Cinar, 1989; Lordoglu, 1990; White, 1994; Kumbetoglu, 1996).

Export-oriented growth has been based on low-cost production and, because the clothing industry is labour intensive, this has required labour costs to be minimised (Ozbay, 1993). For this reason much of the expansion in women's employment has been in the informal sector where regulation of working conditions is very limited (Atauz \& Atauz, 1992).

The Turkish experience indicates that competitive conditions in the manufacture of clothing depend upon flexibility in labour supply as well as flexible structures of production. Labour flexibility was achieved in turbulent market conditions through high rates of labour turnover and through the use of temporary employment to meet increased labour demand associated with short-term economic cycles. Women were central to these processes, suggesting that female labour serves as a reserve army (Braverman, 1974; Berger \& Piore, 1980; Piore \& Sabel, 1984; Jenson, 1994).

\section{(c) Labour Sources}

Parallel to the rapid growth in production and exports, between 1985 and 1990 official statistics show that registered employment in the clothing industry increased by $47 \%$ to reach $7 \%$ of total manufacturing employment in 1990. If undocumented and temporary employees are considered, the clothing industry is likely to account for a substantially higher percentage of the total. Women account for over half $(59 \%)$ of all employees in the clothing industry, similar to the patterns reported elsewhere (Chant \& McIlwaine, 1995).

Most clothing firms are located in large urban centres, and the data collected for this study revealed the main source of female labour to be migrant families. In Turkey, a high rate of natural population increase has combined with considerable rural-to-urban migration to produce very large increases in urban populations [2]. The metropolitan areas have received the largest migratory flows: between 1960 and 1990 the population of Istanbul increased by almost 5 million, with migrants accounting for $50 \%$. The rate of population growth in Istanbul has fallen significantly since 1990 for several reasons, 
including reduced rates of natural increase and rural-to-urban migration, but also because Istanbul has ceased to be so attractive to migrants as cheap land and shelter has been exhausted.

In the initial phases of rural-to-urban migration, migrants generally found employment in the informal sector. Growth in manufacturing industries during the 1960s and 1970s provided some job opportunities in the formal sector but the majority of these went to men. Generally, first-generation female residents of squatter housing areas were reluctant to work outside the home, except to do paid housework, because neither they nor their menfolk were ready to change traditional gender roles. Attitudes began to change among second-generation migrants. Thus, the daughters of rural migrants, either born in metropolitan areas or having migrated at early ages, grew familiar with urban ways of life in which different gender divisions were evident. However, these women did not secure educational or vocational qualifications. Instead they became incorporated into the labour market mainly via the informal sector and became the main source of labour for the clothing industry.

The source of labour drawn upon by the Istanbul clothing industry is not peculiar to Turkey. Research in Mexico (Fernandez-Kelly, 1983a; Beneria \& Roldan, 1987), Brazil (Safa, 1983), Bolivia (Buechler, 1985), the Philippines (Enloe, 1983), Malaysia (Ong, 1983) and Thailand (Porpora et al., 1989) reveals many examples of the textile and clothing industries relying on the labour of women on the margins of urban labour markets.

\section{(d) The Survey}

In order to understand the role of female labour in the restructuring of the clothing industry in Istanbul we set out to interview 500 women working in the industry. Sampling proceeded as follows. First we selected at random 240 clothing firms in Istanbul from the 2397 listed by The Union of the Chambers of Industry and Trade in May 1995. In August and September 1995 we conducted interviews with the managers or owners of these firms, at which we gathered information about the organisation of production, individual workplaces, labour processes, and employees.

Following these interviews, we selected 150 of the firms for the second stage of data collection, ensuring that we included firms involved in all the main stages of production [3]. In February 1996 we interviewed 428 women working for these firms, together with 24 female entrepreneurs who owned firms. The sample included 35 family workers and 48 homeworkers, but was dominated by wage-earners based in workplaces outside their homes (these proportions based on evidence collected in the first stage). A standard schedule was used, with additional sections relevant to particular groups.

\section{Women in the Istanbul Glothing Industry}

\section{(a) Attributes of Female Workers}

The survey as a whole shows that women employed in the clothing industry come from relatively large families and many have other family members also working in clothing production [4]. Interviews reported that as their female children reached working age, the daughters also began to work in the clothing industry. This indicates the importance of the clothing industry as a means of survival within the city. Wages, however, are low: $11 \%$ of the paid workers and $75 \%$ of the homeworkers earn less than the official 
minimum wage. The average figure was reported to be US\$196 per month, which is considerably lower than the average wages of registered employees in either private manufacturing industries (US $\$ 278$ per month) or the state-owned manufacturing industries (US\$384 per month).

On average women employed in the Istanbul clothing industry are young $(54 \%$ were below the age of 25) and poorly educated (64\% reported that they had not proceeded beyond primary school). Just over half are unmarried. However, these averages disguise variations among these workers, which are important in relation to the flexible use of labour. Four major groups can be identified, namely paid workers $(77 \%$ of those interviewed), factory owners (5\% of those interviewed), homeworkers $(10 \%$ of those interviewed) and family workers (8\% of those interviewed). We consider each of these groups in turn.

Paid workers. Among paid workers there are significant variations between those in different occupations. Large numbers are employed directly in production processes. They tend to be drawn from the poorest families and to have the most limited education (65\% have no more than primary schooling and 5\% did not even finish primary school). At the opposite extreme, some women (4\% of those interviewed) work as intermediaries between local and foreign firms and they are university graduates (with PhD degrees) from middle-income families. Women involved in design stages (designing, patternmaking and grading), in marketing, in public relations and in management occupy an intermediate position in terms of their educational and social backgrounds.

Only half of paid workers are registered employees protected by employment law [5]. Almost half of those involved in production work in unregistered firms in the informal sector. In the main these are small workshops located in squatter housing areas where they can access young girls before they finish primary school. These firms do not have a long life: some of them close down after a production season, while others that are more successful go on to register officially (although they continue to use informal labour). In addition to paid workers in unregistered firms, many of those working for registered firms are employed without formal contracts and therefore without any of the protection or benefits of official employees. All those working in unregulated conditions have no entitlement to social security benefits (including access to health care), to holidays, or to limits on working hours, and no access to workplace facilities for children.

Employers generally deduct social security costs direct from wages so that many workers readily accept informal conditions in order to secure the higher take-home pay on offer in the informal sector. For employers this is advantageous since they avoid the legal regulation of employment, for example in relation to working hours. They also avoid additional costs associated with legal rights relating to marriage, birth and children. Consequently marital status is not an issue: employers are concerned only to have employees willing to adapt to changes in demand and especially to accept long working hours.

Homeworkers. Under the pressure of highly competitive market conditions employers often use homeworkers for several reasons: to save on labour costs, to achieve flexibility in the volume of production, and or as a strategy aimed at deunionisation (Peck, 1992). Homeworking is also claimed to be attractive by some women in that it provides an income-earning opportunity, without creating a conflict between paid work and a gender 
ideology that limits women to 'domestic' work. However, to be at the margin of the labour market creates disadvantages, and homeworkers constitute one of the most unprotected groups of workers who are most vulnerable to highly exploitative conditions. This is especially true in Turkey, where there is no mechanism within labour legislation for protecting homeworkers.

Within the study reported here, it is clear that homeworkers are a highly disadvantaged group. They tend to be older than others and to have the lowest levels of education: 19\% of homeworkers were found to be illiterate. Most were from recently arrived migrant families with relatively little experience of urban life and within which married women were under enormous pressure to contribute to their families' income. Most reported that they had become homeworkers following a reduction in family income.

Evidence from several countries indicates that growth in export-oriented garment production often coincides with a rise in the number of homeworkers (Beneria \& Roldan, 1987; Rao \& Husain, 1987; Pineda-Ofreneo, 1988; Gallin, 1990; Singh, 1990). The same pattern was expected in Istanbul. However, data made available by firms in this study, together with anecdotal evidence from several participants, lead us to believe that homeworking is currently decreasing in the Istanbul clothing industry [6]. There are the two broad reasons for this trend. The first concerns labour processes. Young girls provide an alternative to homeworkers: they too can be employed on a very flexible and low-wage basis. Further, because they work within workshops and factories various costs associated with the employment of homeworkers do not apply: materials do not need to be transported between the factory and workers' homes, workers can be moved to different stages of production very quickly, and quality control can be undertaken more easily. These issues have become increasingly important as firms endeavour to meet the swiftly changing demands of fashion markets. Secondly, as we elaborate further in due course, significant changes in women's attitudes to work are also tending to reduce the availability of homeworkers: more and more women want to work on the shopfloor instead of at home.

Factory owners. The interviews showed that almost half the female factory owners surveyed had entered the clothing industry as paid workers, subsequently establishing firms with friends or relatives. During the rapid growth of industry, many small subcontracting workshops were established in this way. In this context female entrepreneurs were able to raise the capital they needed via family circles. On average these women had higher levels of education than others working in this sector, although almost half had only primary school education. Their family origins were broadly similar to those of other women in the study. A second group of female factory owners came from a very different social background. They were the daughters or wives of men who own large businesses and who wished to invest in this sector. While some of the production units owned by this group of female entrepreneurs were essentially subcontractors, others were firms specialising in finished fashion products.

Unpaid family workers. The literature on flexible specialisation emphasises the importance of family enterprises as dynamic agents with the capacity to work on a flexible basis because of their access to unpaid family labour (Capecchi, 1989). However, in the Istanbul study very few such family enterprises were encountered. Only firms newly established by recent migrants fitted the classical profile of family enterprises. In most such businesses the owners' sons run the workshops while their fathers organise outwork 
and other aspects of the business away from the shopfloor. But as workshops began to grow and the number of paid workers increased, capitalist labour relations become dominant even in family enterprises. Thus, most of the young girls working in family businesses received weekly wages in the same way as other workers. Nevertheless, female members of these families, especially daughters and sisters, tended to express dissatisfaction about working in family enterprises because of the extension of patriarchal familial relations into their workplaces. They complained of lacking both the freedom and the opportunity to form new relationships, and of being forced to take on extra work whenever required by market conditions.

\section{(b) Changing Attitudes to Paid Work}

Traditionally in the families of squatter housing areas, women are permitted to work outside only if there is no other way that the family can survive. In other words, such work is not undertaken by choice, and it does not affect the dominant view that the main role of women is at home, with 'good' women necessarily being perfect housewives (White, 1994). The families and social groups to which these women belong may provide assistance to 'enable' women to work outside the home, but they do not want women to become dedicated to such work. Rather, '[i]n traditional families, women gain no individual control over their economic and productive lives and work they do because their labour is in a sense the property of the group' (White, 1994, p. 16). In such a social context women's identity is constructed entirely in relation to family and so the only legitimate reason for undertaking paid work is for the family.

Women's work outside the home does not have a significant impact on the amount and type of domestic work undertaken by women, and they therefore pay a high price to enter the labour market (compare Kagitcibasi, 1979; Kiray, 1985). As in many other contexts married women carry very substantial domestic responsibilities [7], which are even greater for those with children. Amongst married women working in the Istanbul clothing industry $89 \%$ have children, although there are signs that family size is decreasing [8]. While women are able to draw upon local networks to organise childcare, these are generally family-based and serve to strengthen women's obligations to their families (compare Chant \& McIlwaine, 1995). In these circumstances, it might be expected that women would continue to enter the labour market more as family members than as individuals.

Although women began to be incorporated into the labour market for the purposes of increasing family income, the interviews revealed that other factors have become important. Two key changes in women's attitudes to work that challenge dominant domestic codes are demonstrated by this study. First, women no longer define their participation in waged work exclusively in terms of their family roles. One consequence of this is that they rarely leave work for family reasons such as marriage or motherhood. Moreover, although marriage is still a major means of achieving social status and respectability, women seem to be less willing to get married as they start to earn their own wages (compare Bolles, 1985; Fernandez-Kelly, 1983b; Safa, 1983). In this context it should also be noted that preparing a trousseau, which was widely emphasised in earlier studies of women's participation in the clothing industry (White, 1994), was insignificant except for a few family workers. Secondly, there is unambiguous evidence that women now make their own decisions about whether or not to work outside the home: $80 \%$ stated that it is solely their decision to take on such work; only $16 \%$ reported making the decisions with their husbands or with other family members. Many of the 
women interviewed $(47 \%)$ said that they started work in order to make use of their skills, and many spoke of their desire to be out of the home. The great majority spoke of waged work as a way of life and did not contemplate quitting. These motivations reinforce the argument that women have shifted from seeing themselves solely in relation to their families to assume more individualistic and autonomous identities.

\section{(c) Responses to Working Conditions}

The contemporary female labour force of the clothing industry clearly does not fit the image of being passive and dependent. Moreover, while some resistance to women working outside the home persists, the majority of families have participated in this transformation in attitudes (Ecevit, 1991; Senyapili, 1992). However, while the great majority of women now want to work outside the home $(81 \%$ of those interviewed), this does not mean they are satisfied with the work they are engaged in or with their conditions at work or at home. Indeed, with experience of the labour market they tend to develop increased awareness of strategies through which they might enhance their situation. Three such strategies can be identified [9].

The first strategy entails a search for better working conditions through job mobility. Working hours in clothing factories and workshops usually entail 9-10 hours a day, 5 days a week. However, 25\% of the women worked 6 days a week and $7 \%$ worked 7 days a week. Although working all night in high-demand periods is not exceptional, overtime payments are only assured in big firms. In addition to responding to these considerations in their work histories, women expressed a clear preference for firms that export their products to Russia or Eastern European countries, which tend to be less acutely concerned about quality control.

Secondly female employees try to increase their wages. Women have attempted to take advantage of the intense demand for their labour associated with the rapid expansion of clothing production since the early 1980s. In relation to subcontractors in the informal sector in particular, experienced female workers have acquired significant bargaining power. These women are needed by new firms keen to establish themselves very swiftly within production networks. In these conditions workers can move from one firm to another in pursuit of higher wages. In the informal sector employees work without being registered for social security benefits, the most important of which is access to health care services. However, in the Turkish system it is possible to use health care services if one person in the family is registered. Consequently families attempt to ensure that one member is registered, but for other family members it is more advantageous to seek wages from which benefits are not deducted.

The third strategy entails attempting to escape from patriarchal relations. Although the restructuring of production has brought about changes in gender relations within workplaces, patriarchal forms still exist, especially in small firms. Indeed factory owners and managers often emphasise this, arguing that they consider their employees to be part of 'a family' and claiming to regard women workers as their own sisters or daughters. This kind of discourse supports deeply ingrained ideas about women's social roles and is used to reassure men that their control over women extends into workplaces: it has served as a means of overcoming resistance to the employment of women outside the home, especially where they work side by side with men. But women have increasingly challenged such patriarchal structures, both through their job aspirations and through their choice of workplace. In relation to the former, most of the women interviewed stated that they want to improve their positions at their workplaces and some of them 
aspired to jobs as machine operators, which command high wages. In relation to the latter, women articulated clear preferences about the workplaces relative to their homes. A substantial number of the paid workers $(40 \%)$ indicated that they wanted to work a considerable distance from home. Most of these women were single and they clearly wanted to escape from the control exerted by their home environments, whether through their immediate families, other relatives or neighbours. They wanted to work somewhere they could move about freely during their lunch breaks, taking the opportunity to meet with friends, including boyfriends. Some employers stated that, despite offering higher than average wages, they have difficulty in recruiting workers because of a lack of meeting places in the vicinity of their firms. On the other hand, most married women said they prefered workplaces within their neighbourhood so that they can get home swiftly to attend to the housework awaiting them.

\section{The Impact of Women Workers on the Restructuringof Clothing Production in Istanbul}

The findings reported here cast doubt on the claim that women employed in the clothing industry in Istanbul inhabit the margins of the labour market. Many women do not want to be drawn in and out of the labour market according to demand conditions: they want to incorporate work into their lives permanently and they seek to improve their working positions. While this does not mean that women are determining the pattern of industrial development, their increasing power has important repercussions for the labour market and for conditions of production.

Women's response to expanding labour demand is pushing wages up. This trend is set to continue given the high cost of living in the Istanbul Metropolitan Area. This undermines the historical basis of the Istanbul clothing industry's capacity to compete in international markets. In order to sustain their competitive position in such conditions, factory owners may initiate further restructuring in two main ways: they may relocate in lower wage localities, or they may shift into the production of goods with higher added value, notably fashion-sensitive products. Neither is without disadvantages but there is evidence of both occurring in the Istanbul clothing industry. We comment briefly on each in turn.

Some of the factory owners interviewed indicated their intention to expand production in new areas, outside Istanbul. While this is a means by which labour costs can be cut, peripheral, low-wage areas isolate firms from the networks of subcontractors that have been so important in the expansion of the industry. Moreover, whether the savings achieved by relocation will enable them to sustain their competitive advantage is unknown, since there are more and more competitors in the production of standard clothing products based in low wage countries.

Other factory owners stated that the only possibility for them was to shift into the production of fashion-sensitive goods. This requires further changes in the organisation of production in labour processes. Firstly, as Storper \& Scott (1984) argue, parent firms may have to internalise some production stages in order to overcome some of the risks of subcontracting, but this may put in jeopardy the survival of the firm itself. Secondly, in fashion-sensitive production, design, marketing and public relations jobs form a larger proportion of the total. But this means accessing a very different segment of the labour market than that constituted by second generation migrants from rural areas. This shift is therefore associated with a major restructuring of the urban labour market (compare Beneria \& Roldan, 1987). 
The risks associated with both approaches to sustaining competitive advantage suggest that the capacity of women workers in the Istanbul clothing industry to sustain their enhanced bargaining power may be limited and temporary. While export-oriented clothing production brought advantages for women on the margins of the metropolitan area, the aspirations fostered by it and the bargaining power accruing to women workers is prompting further forms of restructuring, which may, in the long run, exclude at least some of them.

The research on the Istanbul clothing industry discussed in this article indicates that the flexible production system, with its lack of vertical integration, that has expanded so rapidly since the early 1980s, depended upon a pool of second-generation female migrants in order to compete within global markets. During this period of growth, women, more than $80 \%$ of whom came from families migrating to Istanbul from rural areas, have become an integral part of the labour market. In so doing their own attitudes to work, and behaviour as workers, have changed. As a result they are now active agents in the labour market and the terms 'marginal' or 'reserve labour' no longer accurately describe their roles in the labour market. The increasing bargaining power of this group, and the wage rises they have succeeded in gaining, are generating further processes of restructuring. Thus, the labour market effects of one round of restructuring are influencing the form of the next round.

\section{NOTES}

[1] This is why the Customs Union Agreement in 1996 between Turkey and Europe had minimal impact on clothing exports.

[2] Between 1950 and 1990 Turkey's urban population increased by nearly 28 million, of which migration accounted for some $14 \%$.

[3] The production stages were grouped into three: (a) those involving pattern-making, grading, cutting, and public relations, which tend to involve the most highly skilled tasks, (b) sewing, and (c) quality control and packaging.

[4] The average number of people in the families of the women in our sample is 4.6 and the average number of people working in those families is 2.5 .

[5] Of the $51 \%$ of the female workers protected by social security schemes, the great majority (95\%) are covered by the Social Security Institution, with the remainder divided between the Social Security Institution for People Working Independently and private social security providers.

[6] Data reliablity is problematic in relation to homeworking, with most managers and factory owners stating that they do not know how many such workers they employ. But the offical records indicate a $30 \%$ decline between August 1993 and August 1995.

[7] According to the research in Istanbul, 51\% of the married women take on full responsibility for all housework within their own homes, and $24 \%$ get help from other female members of their family, such as a mother, mother-in-law, sister, or sister-in-law. Only 13\% report sharing the housework with their husbands or other members of their family, while $12 \%$ reported paying others to work in their homes.

[8] Of the women interviewed $34 \%$ had one child, $44 \%$ had two children, and $11 \%$ had three or more.

[9] Dissatisfaction about work and about women's roles in the family and society is also expressed via aspirations for daughters and sons.

\section{REFERENCES}

Allen, Sheila \& Wolkowitz, Carol (1987) Homeworking: myths and realities (London, Macmillan).

Ansal, Hacer (1995) Teknolojik Gelismelerin Sanayide Kadin Istihdamina Etkileri: Turk Dokuma ve Elektronik Sanayilerinde Teknolojik Degisim ve Kadin Istihdami Arastirmasi. Unpublished report prepared for the Ministry of Women Affairs.

Atauz, Sevil \& Atauz, Akin (1992) Enformel Sektor, Kentsel Isgucu Pazarlari, Sosyal ve Ekonomik Yapilanmalar Uzerinde Betimsel Tartismalar, Planlama, 1, pp. 4-12. 
Beneria, Lourdes \& Roldan, Martha (1987) The Crossroads of Class and Gender: industrial homework, subcontracting and household dynamics in Mexico City (Chicago, IL, University of Chicago Press).

Benton, Lauren (1989) Industrial subcontracting and the informal sectors: the politics of restructuring in the Madrid electronics industry, in: Alejandro Portes, Manuel Castells \& Lauren Benton (Eds) The Informal Economy. Studies in Advanced and Less Developed Countries, pp. 228-244 (Baltimore, MD, Johns Hopkins University Press).

Benton, Lauren (1990) Invisible Factories: the informal economy and industrial development in Spain (Albany, NY, State University of New York Press).

Berger, Suzanne \& Piore, Michael (1980) Dualism and Discontinuity in Industrial Societies (Cambridge, Cambridge University Press).

Bolles, A. Lynn (1985) Economic crisis and female-headed households in urban Jamaica, in: JunE NASH \& Helen SAFA (Eds) Women and Change in Latin America, pp. 65-83 (New York, Bergin \& Garvey).

BORATAV, KORKUT (1988) Turkiye Iktisat Tarihi (Istanbul, Gercek).

Braverman, Harry (1974) Labor and Monopoly Capital (New York, Monthly Review Press).

Buechler, Judith-Maria (1985) Women in petty commodity production in La Paz, Bolivia, in: June Nash \& Helen Safa (Eds) Women and Change in Latin America, pp. 165-188 (New York, Bergin \& Garvey).

CAPECCHI VitTorio (1989) The informal economy and the development of flexible specialization in Emilia-Romagna, in: Alejandro Portes, Manuel Castells \& Lauren Benton (Eds) The Informal Economy. Studies in Advanced and Less Developed Countries, pp. 189-215 (Baltimore, MD, Johns Hopkins University Press).

Castells, Manuel \& Portes, Alejandro (1989) World underneath: the origins, dynamics and effects of the informal economy, in: Alejandro Portes, Manuel Castells \& Lauren Benton (Eds) The Informal Economy. Studies in Advanced and Less Developed Countries, pp. 11-37 (Baltimore, MD, Johns Hopkins University Press).

Chant, Sylvia \& McilWaine, Cathy (1995) Gender and export manufacturing in the Philippines: continuity and change in female employment? The case of the Mactan Export Processing Zone Gender, Place and Culture, 2, pp. 147-176.

Cheng, Lu-Lin \& Gereffi, Gary (1994). The informal economy in East Asian development, International fournal of Urban and Regional Research, 18, pp. 194-219.

Christopherson, SUSAN (1989) Flexibility in the US service economy and the emerging spatial division of labour, Transactions of the Institute of British Geographers, 14, pp. 131-143.

Cinar, Mine (1989) Taking work at home: disguised female employment in urban Turkey, Loyola University of Chicago School of Business Administration Working Paper No. 8810 (Chicago, IL, Loyola University).

Ginar, Mine, Evcimen, Gunar \& Kaytaz, Mehmet (1988) The present day status of small-scale industries (sanatkar) in Bursa, Turkey, International Journal of Middle East Studies, 20, pp. 287-301.

Doeringer, Peter B. \& Piore, Michael J. (1985) Internal Labor Markets and Manpower Analysis, 2nd edn (New York, M. E. Sharp).

ECEVIT, Yildiz (1991) Shop floor control: the ideological construction of Turkish women factory workers, in: Nanneke Redclift \& M. Thea Sinclair (Eds) Working Women: international perspectives on labour and gender and ideology, pp. 56-78 (London, Routledge).

Enloe, Cynthia H. (1983) Women textile workers in the militarization of Southeast Asia, in: June NASH \& Maria Patricia Fernandez-Kelly (Eds) Women, Men and the International Division of Labour, pp. 405-425 (Albany, NY, State University of New York Press).

ERAYdin, AYda (1993) The new international relations, restructuring in the economy and the emerging changes in the business behaviour, in: Chris Rogerson, Eike Schamp \& Godfrey J.R. Linge (Eds) Business Behaviour, Markets, Finance and Industrial Change, pp. 183-203 (Berlin, Gruyter).

ERAYDin, AYDA (1994) Changing spatial distribution and structural characteristics of Turkish manufacturing industry, in: Fikret Senses (Ed.) Recent Industrialization Experience of Turkey in a Global Context, pp. 155-174 (London, Greenwood Press).

Eraydin, Ayda \& Erendil, Asuman (1998) Dis Pazarlara Acilan Konfeksiyon Sanayinde Yeni Uretim Surecleri ve Kadin Isgucunun Bu Surece Katilim Bicimleri (Ankara, KKSGM).

Fernandez-Kelly, Maria Patricia (1983a) For We Are Sold, I and My People: women and industry in Mexico's frontier (Albany, NY, State University of New York Press).

Fernandez-Kelly, Maria PAtricia (1983b) Mexican border industrialization, female labour force participation, and migration, in: June Nash \& Maria Patricia Fernandez-Kelly (Eds) Women, Men and the International Division of Labour, pp. 205-223 (Albany, NY, State University of New York Press).

Gallin, Rita S. (1990) Women and the export industry in Taiwan: the muting of class consciousness, in: KATHRYN B. WARD (Ed.) Women Workers and Global Restructuring, pp. 179-192 (Ithaca, NY, ILR Press).

Hartmann, Heidi (1987) Changes in women's economic and family roles in post World War II United States, 
in: Lourdes Beneria \& Catharine Stimpson (Eds) Women, Households and the Economy, pp. 33-64 (News Brunswick, NJ, Rutgers University Press).

Horton, Susan (1996) Women and Industrialization in Asia (London, Routledge).

JEnson, Jane (1994) The talents of women, the skills of men: flexible specialization and women, in: STEPHEN Wood (Ed.) The Transformation of Work, pp. 141-149 (London, Unwin Hyman).

Kagitcibasi, Cigdem (1979) Turkiye'de kadinin degeri, kadinin rolu ve dogurganligi, in: Nermin AbadanUnat (Ed.) Turk Toplumunda Kadin, pp. 89-115 (Ankara, Türk Sosyal Bilimler Dernegi).

KAYASU, SERAP (1995) Local production organization oriented towards global markets: subcontracting relationships in clothing industry, PhD thesis, Ankara, Middle East Technical University.

Kaytaz, Mehmet (1994) Subcontracting practice in the Turkish textile and metal working industries, in: Fikret Senses (Ed.) Recent Industrialization Experience of Turkey in a Global Context, pp. 141-154 (London, Greenwood Press).

KaZgan, G. (1985) Ekonomide Disa Acik Buyume (Istanbul, Altin Kitaplar).

Kessler-Harris, Alice \& Sacks, Karen Brodkin (1987) The demise of domesticity in America, in: Lourdes Beneria \& Catharine Stimpson (Eds) Women, Households and the Economy, pp. 65-84 (New Brunswick, NJ, Rutgers University Press).

Kiray, Mubeccel B. (1985) Metropolitan city and the changing family, in: Turkoz Erder (Ed.) Family in Turkish Society: sociological and legal studies, pp. 79-92 (Ankara, Turk Sosyal Bilimler Dernegi).

Kumbetoglu, Betul (1996) Gizli Ysciler: Kadinlar ve Bir Alan Arastirmasi, in: Selmin Cakir \& Nermin Akgokce (Eds) Kadin Arastirmalarinda Yontem, pp. 230-238 (Ankara, Sel Yayincilik).

Lamphere, LOUISE (1987) From Working Daughters to Working Mothers: immigrant women in a New England industrial community (Ithaca, NY, Cornell University Press)

LAWSON, Victoria A. (1992) Industrial subcontracting and employment in Latin America: a framework for contextual analysis, Progress in Human Geography, 16, pp. 1-23.

Lipietz, Alain (1986) New tendencies in international division of labour: regimes of accumulation and modes of regulation, in: Allen J. Scott \& Michael Storper (Eds) Production, Work and Territory, pp. 16-35 (London, Allen \& Unwin).

Lordoglu, Kudret (1990) Eve Is Verme Sistemi Icinde Kadin Isgucu Uzerine Bir Alan Arastirmasi (Istanbul, Friedrich Ebert Vakfi Publications).

MAssey, Doreen (1984) Spatial Divisions of Labour: social structures and the geography of production (London, Macmillan).

Mies, Maria (1986) Patriarchy and Accumulation on a World Scale (London, Zed Books).

Olgun, Hasan \& Togan, Subitey (1984) Turk Ekonomisinin Dunya Ekonomisine Entegrasyonu (Istanbul, Enka). ONG, AIHWA (1983) Global industries and Malay peasants in peninsular Malaysia, in: JunE NASH \& MARIA Patricia Fernandez-Kelly (Eds) Women, Men and the International Division of Labour, pp. 426-439 (Albany, NY, State University of New York Press).

Ozbay, Ferhunde (1993) Kadinlarin evici ve evdisi ugraslarinda degisme, in: Sirin TeKeli (Ed.) 1980’ler Turkiye'sinde Kadin Bakis Acisindan Kadinlar, pp. 117-128 (Istanbul, Yletisim).

PECK, JAMIE (1992) Invisible threads: homeworking, labor market relations and industrial restructuring in the Australian clothing trade, Environment and Planning D, 10, 671-89.

Peck, Jamie (1996) Work-place: the social regulation of labor markets (New York, Guilford Press).

Pessar, Patricia R. (1994) Sweatshop workers and domestic ideologies: Dominican women in New York's apparel industry, International fournal of Urban and Regional Research, 18, pp. 127-142.

Phizacklea, Annie \& Wolkowitz, Carol (1995) Homeworking Women (London, Sage).

Pincheson, Edward (1993) Textiles and clothing in Turkey: Part 1, Textile Outlook International, 11, pp. $105-129$.

Pincheson, Edward (1994) Textiles and clothing in Turkey: Part 2, Textile Outlook International, 1, pp. $124-142$. Pineda-Ofreneo, Rosalinda (1988) Philippines domestic outwork: subcontracting for export oriented industrialization, in: John G. Taylor \& Andrew Turton (Eds) Sociology of Developing Societies: South East Asia, pp. 158-164 (Basingstoke, Macmillan).

Piore, Michael \& Sabel, Charles F. (1984) The Second Industrial Divide (New York, Basic Books).

Porpora, Douglas V., Lim, Mah Hui \& Prommas, Usanee (1989) The role of women in the international division of labour: the case of Thailand, Development and Change, 20, pp. 269-294.

Prieto, Yolanda (1986) Women, work and change: the case of Cuban workers in the: US, Latin American Monograph Series 9 (Mercyhurst, PA, Northwestern Pennsylvania Institute for Latin American Studies).

Rao, Rukmini \& Husain, Sahba Husain (1987) Women in the garment export industry, in: Andrea Menefee Singh \& Anita Kelles-Vitanen (Eds) Invisible Hands: women in home-based production (New Delhi, Sage). 
SAFa, Helen (1983) Women, production and reproduction in industrial capitalism: a comparison of Brazilian and US factory workers, in: June Nash \& Maria Patriaia Fernandez-Kelly (Eds) Women, Men and the International Division of Labour pp. 95-116 (Albany, NY, State University of New York Press).

Scott, Allen \& Storper, Michael (1986) Production, Work and Territory: the Geographical Anatomy of Industrial Capitalism (Berkeley, CA, University of California Press).

Senses, Fikret (1989) 1980 Sonrasi Ekonomi Politikalari Isiginda Turkiye'de Sanayilesme (Ankara, V Yayinlari).

Senyapili, TAnsi (1992) A new stage of gecekondu housing in Istanbul, in: Ilhan Tekeli (Ed.) Development of Istanbul Metropolitan Area and Low Cost Housing, pp. 98-127 (Istanbul, Turkish Social Science Association).

Singh, Andrea Menefe (1990) The Political Economy of Unorganised Industry: a study of labour process (New Delhi, Sage).

Storper, Michael \& Scott, Allen J. (1984) Industrial organization and the logic of intra-metropolitan location III: a case study of the women's dress industry in the Greater Los Angeles region, Economic Geography, 60 , pp. $3-27$.

Storper, Michael \& Scott, Allen J. (1986) Production, work and territory: contemporary realities and theoretical tasks, in: Allen J. Scott \& Michael Storper (Eds) Production, Work and Territory, pp. 3-15 (London, Allen \& Unwin).

Storper, Michael \& Walker, Richard (1983) The theory of labour and the theory of location, International Journal of Urban and Regional Research, 7, pp. 1-43.

Storper, Michael \& WAlker, Richard (1989) The Capitalist Imperative: territory, technology and industrial growth (Oxford, Basil Blackwell).

Stratigaki, M. \& VAiou, D. (1994) Women's work and informal activities in Southern Europe Environment and Planning A, 26, pp. 1221-1234.

Tickell, AdAm \& Peck, Jamie (1992) Accumulation, regulation and the geographies of post-Fordism: missing link in regulationist research, Progress in Human Geography, 16, pp. 190-218.

Walby, Sylvia (1990) Theorizing Patriarchy (Oxford, Blackwell).

White, Jenny B. (1994) Money Makes Us Relatives: women's labor in urban Turkey (Austin, TX, University of Texas Press). 